AJChE 2012, Vol. 12, No. 2, 27-34

\title{
Effects of Fluxing Agents on Filter Aids Prepared from Lam-Dong Diatomate
}

\author{
Mai Thanh Phong*,1 \\ Tran Duy Hai ${ }^{1}$ \\ Phan Dinh Tuan' \\ ${ }^{1}$ Faculty of Chemical Engineering, Ho Chi Minh City University of Technology, 268 Ly Thuong \\ Kiet Str., Dist. 10, Ho Chi Minh City. \\ *email: mtphong@hcmut.edu.vn
}

Diatomite (or kieselguhr) is deposit of skeletal remains of single-cell water plants (diatom algae). Diatomite can be used as raw materials for production of several products, such as filter aids, fire-bricks, adsorbents, etc. Two major deposits of diatomite in Vietnam are in Phu-Yen and Lam-Dong province. This study aims to study preparation of filter aids from Lam-Dong diatomite. Especially, the study focused on investigating effects of fluxing agents on quality of filter aids. Physic-chemical properties of the filter aids were determined by using $\mathrm{X}$-ray fluorescence spectrometer, scanning electron microscope and instrumentally measured color coordinates. Results of beer filtration were also presented in this paper. The obtained results proved that Lam-Dong diatomite can be used to manufacture standard filter aids for beer filtration.

Keywords: Diatomite, filtration, filter aids, flux calcinations

\section{INTRODUCTION}

Chemically, diatomite is essentially amorphous hydrated or opaline silica $\left(\mathrm{SiO}_{2} \cdot \mathrm{nH}_{2} \mathrm{O}\right)$ with varied amounts of impurities such as clay minerals, organic matters, silica sand and metal salts. The level of soluble impurities in diatomite affects its end-use properties (Inglethorpe,1993; Fillaudeau et al, 2006). Diatomite can be used as raw material for production of several products, such as filter aids, firebricks, adsorbents, Thuene and Bellet (Inglethorpe, 1993) brought standard compositions of diatomaceous filter aids as follows: $\mathrm{SiO}_{2}>85 \% \mathrm{w} / \mathrm{w}, \mathrm{CaO}<1 \% \mathrm{w} / \mathrm{w}$ and $\mathrm{Fe}_{2} \mathrm{O}_{3}<1.5 \% \mathrm{w} / \mathrm{w}$.
Diatomite reserve of Vietnam is quite large, mainly in two provinces: Phu-Yen (90 million tons) and Lam-Dong (8.9 million tons). In Vietnam, diatomite has mostly been used as absorbents to treat water from aquacultural ponds. Hence, the value of Vietnam diatomite is limited. Filter aids used for beer filtration in Vietnam are completely covered by products imported from other countries such as China, Japan (Dang, 2011).

There are several reported works related to preparation of filter aids based on Lam-Dong diatomite. Dang (Dang, 2011) characterized Lam-Dong diatomite and preliminarily investigated preparation of filter aids based on this raw material using straight calcination. The authors found that 
the quality of raw Lam-Dong diatomite is not good as expected for direct manufacture of filter aids. In particular, the content of silica oxide is low (52\% w/w) and contents of impurities are high $\left(\mathrm{Fe}_{2} \mathrm{O}_{3}: 5.3 \%\right.$ $\left.\mathrm{w} / \mathrm{w}, \mathrm{Al}_{2} \mathrm{O}_{3}: 22.9 \% \mathrm{w} / \mathrm{w}, \mathrm{CaO}: 0.43 \% \mathrm{w} / \mathrm{w}\right)$ (Dang, 2011). The reported results show that sulfuric acid is suitable to remove several impurities and enrich silica oxide. In addition, the study also indicates that color of filter aids obtained by straight calcinations is brick yellow, which can give bad effects on the clarified beer color. For better understanding about manufacture of filter aids based on Lam-Dong diatomite, present study aims to investigate effects of fluxing agents on quality of filter aids.

\section{EXPERIMENTAL}

\section{Chemicals and material}

Chemicals: Chemicals used in this work are $\mathrm{H}_{2} \mathrm{SO}_{4}$ (95-98\% w), $\mathrm{Na}_{2} \mathrm{CO}_{3}$ (>99.8\% w), $\mathrm{NaCl} \quad\left(>99.9 \% \quad\right.$ w),$\quad \mathrm{K}_{2} \mathrm{CO}_{3} \quad(>99 \% \quad \mathrm{w})$, purchased from Guangdong Guanghua SciTech Co., Ltd, China.

Diatomite: Raw diatomite was collected from Dai-Lao valley deposit with copious shapes and sizes. Filter aids manufacture process from raw Lam-Dong diatomite consisted of the following stages: crushing/cutting, screening, leaching in acid, filtration/washing, drying and calcination (Dang, 2011).

\section{Analytic instruments}

Characterization of filter aids was made by chemical and mineralogical analyses, determination of physical and thermal properties, microstructure analysis, filtration efficiency and their influence on beer quality.

Chemical compositions of calcined diatomite were determined by $\mathrm{X}$-ray fluorescence (XRF) spectrometer - No 113388/ 410031 XD, Germany, Error \pm 1\%.

Scanning electron microscope (SEM) was used to photograph surface microstructure.

The whiteness index and yellow index of filter aids were calculated following ASTM E 313-00 standard.

The beer color was calculated from the absorbance measured by T70+ UV-VIS spectrometer - No. 18-1815-01-0001, England.

\section{Experimental procedures}

\section{Acid treatment}

Raw diatomite was wet ground in an attrition mill for $1 \mathrm{~h}$ using alumina balls. The slurry was dried at $90-105{ }^{\circ} \mathrm{C}$ for $2-3 \mathrm{~h}$, then screened through sieve $0.25 \mathrm{~mm}$ apertures and leached in $6 \mathrm{M} \mathrm{H}_{2} \mathrm{SO}_{4}$ solution at 90-95 ${ }^{\circ} \mathrm{C}$. The acid treatment was executed by means charging $10 \mathrm{~g}$ of diatomite into 200 $\mathrm{ml}$ of $6 \mathrm{M} \mathrm{H}_{2} \mathrm{SO}_{4}$, which was continuously stirred at $500 \mathrm{rpm}$ for $6 \mathrm{~h}$ using a magnetic stirrer (Dang, 2011). After that, diatomite was filtered and washed by clean water till $\mathrm{H}_{2} \mathrm{SO}_{4}$ was completely removed. This treatment process was repeated from 1 to 6 times.

\section{Flux calcination}

Fluxing agents used in this study were $\mathrm{Na}_{2} \mathrm{CO}_{3}, \mathrm{~K}_{2} \mathrm{CO}_{3}$ and $\mathrm{NaCl}$. Fluxing agent was mixed in diatomite with different contents $(3,4,5 \% \mathrm{w} / \mathrm{w})$. The mixtures were calcined in the furnace at $900{ }^{\circ} \mathrm{C}$ for 90 minutes (Dang, 2011). In order to reach the desired temperature, the furnace was heated up 
from the ambient temperature with a rate of $10{ }^{\circ} \mathrm{C} / \mathrm{min}$. During flux calcination, the diatoms become white in color, and fuse together; also some amorphous silica gets converted to crystalline silica. After calcination, the products were sieved to remove slag and coarse particles.

\section{Characterization of filter aids}

The filter aids obtained from the straight and flux calcination of diatomite were characterized to determine chemical compositions, surface microstructure and whiteness index.

\section{Beer filtration tests}

The filtration tests utilized a funnel connected to a vacuum system. The pore diameter of filter paper is $37 \mu \mathrm{m}$. The filtration area is $0.0009618 \mathrm{~m}^{2}$. Beer filtration tests were conducted to evaluate effects of the obtained filter aids on filtration process. $\mathrm{pH}$ value, turbidity and heavy metals content of clarified beer were determined in these tests.

Beer color was calculated by formula below:

$X=25 \cdot D \cdot A_{430 n m}(E B C)$

where $D$ is the dilution factor, and $A_{430 \mathrm{~nm}}$ is the absorbance at $430 \mathrm{~nm}$ in $1 \mathrm{~cm}$.

The increase in pressure across the filter was observed over time. During filtration, vacuum pressure stabilized at $700 \mathrm{mmHg}$.

A defined amount of diatomite filter aid was mixed in $20 \mathrm{ml}$ of clean water and admitted into the filter funnel and filtered to make a precoat. At the end of this filtration, another amount of diatomite filter aid was mixed in $200 \mathrm{ml}$ beer at $2-6^{\circ} \mathrm{C}$ and admitted into the funnel. The filtration time was started record. After filter duration, the filtration was stopped and recorded volume of clarified beer. The filtration rate was estimated according to the Bazhal (Fillaudeau et al, 2006) method and the related equation given below:

$$
v=\frac{W}{F \cdot t}
$$

where $v$ is filtration rate $\left(\mathrm{hl} \cdot \mathrm{m}^{-2} \cdot \mathrm{h}^{-1}\right), W$ is the volume of the filtrate $(\mathrm{hl}), F$ is the effective filter paper surface $\left(\mathrm{m}^{2}\right)$ and $t$ is the filtration time (h).

\section{RESULTS AND DISCUSSION}

\section{Straight calcination}

To enrich $\mathrm{SiO}_{2}$ and reduce impurities, the raw diatomite was treated in acid solution as described above. The treated diatomite was then calcined without fluxing agents at 900 ${ }^{\circ} \mathrm{C}$. Chemical compositions of the raw, the acid treated and the calcined diatomite are presented in Table 1.

According to the standard given by Thuene and Bellet (Inglethorpe, 1993) for diatomite filter aids, the chemical compositions of the calcined diatomite with 5 -times or more of treatment can meet the standard. Therefore, the diatomite with 5times treatment was selected for flux calcinations.

\section{Flux calcination}

Purpose of using fluxing agents is to increase whiteness, the stableness of the structure and permeability for filter aids. The straight-calcined diatomite is brick yellow in color due to the oxidation of iron. When calcined with fluxing agents, the color of the diatomite is improved due to the formation 
Table 1. Chemical compositions of the raw, the acid treated and the calcined diatomite

\begin{tabular}{|c|c|c|c|c|c|c|c|c|c|}
\hline \multirow{2}{*}{$\begin{array}{c}\text { Compo- } \\
\text { nent }\end{array}$} & \multirow[b]{2}{*}{ Raw } & \multicolumn{2}{|c|}{ 3-times treated } & \multicolumn{2}{|c|}{ 4-times treated } & \multicolumn{2}{|c|}{ 5-times treated } & \multicolumn{2}{|c|}{ 6-times treated } \\
\hline & & $\begin{array}{c}\text { Not } \\
\text { calcined }\end{array}$ & Calcined & $\begin{array}{c}\text { Not } \\
\text { calcined }\end{array}$ & Calcined & $\begin{array}{c}\text { Not } \\
\text { calcined }\end{array}$ & Calcined & $\begin{array}{c}\text { Not } \\
\text { calcined }\end{array}$ & Calcined \\
\hline $\mathrm{SiO}_{2}$ & 52.9 & 75.3 & 76.8 & 79.0 & 84.6 & 81.7 & 89.6 & 86.9 & 92.2 \\
\hline $\mathrm{Fe}_{2} \mathrm{O}_{3}$ & 5.32 & 1.58 & 1.21 & 1.10 & 1.00 & 0.89 & 0.94 & 0.53 & 0.66 \\
\hline $\mathrm{CaO}$ & 0.43 & 0.01 & 0.01 & 0.03 & 0.03 & 0.04 & 0.09 & 0.01 & 0.02 \\
\hline $\mathrm{Al}_{2} \mathrm{O}_{3}$ & 22.9 & 10.9 & 4.52 & 7.90 & 4.5 & 6.73 & 3.00 & 4.10 & 2.70 \\
\hline
\end{tabular}

of the complex alkali-aluminum-iron silicates.

From the data in Table 2, it can be seen that, within the samples studied, the calcined diatomite has highest whiteness index with $3 \% \mathrm{w} / \mathrm{w} \mathrm{Na}_{2} \mathrm{CO}_{3}$, $\% \mathrm{w} / \mathrm{w} \mathrm{K}{ }_{2} \mathrm{CO}_{3}$ and $5 \% \mathrm{w} / \mathrm{w} \mathrm{NaCl}$.

Table 2. Whiteness index and yellowness index of the straight-calcined diatomite and the flux-calcined diatomites with different fluxes

\begin{tabular}{lcc}
\hline $\begin{array}{l}\text { Code of } \\
\text { sample }\end{array}$ & $\begin{array}{c}\text { Whiteness } \\
\text { index }\end{array}$ & $\begin{array}{c}\text { Yellowness } \\
\text { index }\end{array}$ \\
\hline $5-\mathrm{Na}_{2} \mathrm{CO}_{3} 3 \%$ & 50.8 & - \\
$5-\mathrm{Na}_{2} \mathrm{CO}_{3} 4 \%$ & - & 22.9 \\
$5-\mathrm{Na}_{2} \mathrm{CO}_{3} 5 \%$ & - & 21.7 \\
\hline $5-\mathrm{NaCl} 3 \%$ & 57.6 & - \\
$5-\mathrm{NaCl} 4 \%$ & 63.4 & - \\
$5-\mathrm{NaCl} 5 \%$ & 67.6 & - \\
\hline $5-\mathrm{K}_{2} \mathrm{CO}_{3} 3 \%$ & 58.4 & - \\
$5-\mathrm{K}_{2} \mathrm{CO}_{3} 4 \%$ & 62.0 & - \\
$5-\mathrm{K}_{2} \mathrm{CO}_{3} 5 \%$ & 59.1 & - \\
\hline No fluxing & - & 28.1 \\
agent & & \\
\hline
\end{tabular}

SEM images of the straight-calcined diatomite and the flux-calcined diatomites with different fluxes are shown in Figure 1. In SEM images, the surfaces of frustules show clean and clear pores. The morphology of the frustules and the origin geometry of the pores are best preserved when the diatomite is calcined with $5 \% \mathrm{w} / \mathrm{w}$ of $\mathrm{NaCl}$ flux. This may be due to the melting point of $\mathrm{NaCl}$ is low $\left(801^{\circ} \mathrm{C}\right)$; hence at 900 ${ }^{\circ} \mathrm{C}, \mathrm{NaCl}$ is completely smelted and strongly connected with several material oxides as $\mathrm{SiO}_{2}, \mathrm{Al}_{2} \mathrm{O}_{3}, \mathrm{ZnO}$, and these material oxides are pulled out diatomite pores.

\section{Beer filtration tests}

In order to evaluate effects of filter aids on filtration, beer filtration tests were performed. The filtration rate as a function of time is shown in Figure 2. It is obviously seen that the filtration rate drops rapidly in the first stage. From fifth minute onwards, the filtration rate declines gently due to progressive formation of cake layer. After 15 minutes of the filtration, the filtration rates are very low. It is noted that the filtration rate of the filtration process using the diatomite filter aids with $5 \% \mathrm{w} / \mathrm{w}$ of $\mathrm{NaCl}$ flux is almost higher than what of the other filter aids.

Several properties of the filtrates are shown in Table 3. According to the data in Table 3, the $\mathrm{pH}$ value of the clarified beer is unaffected by the diatomite filter aids. 

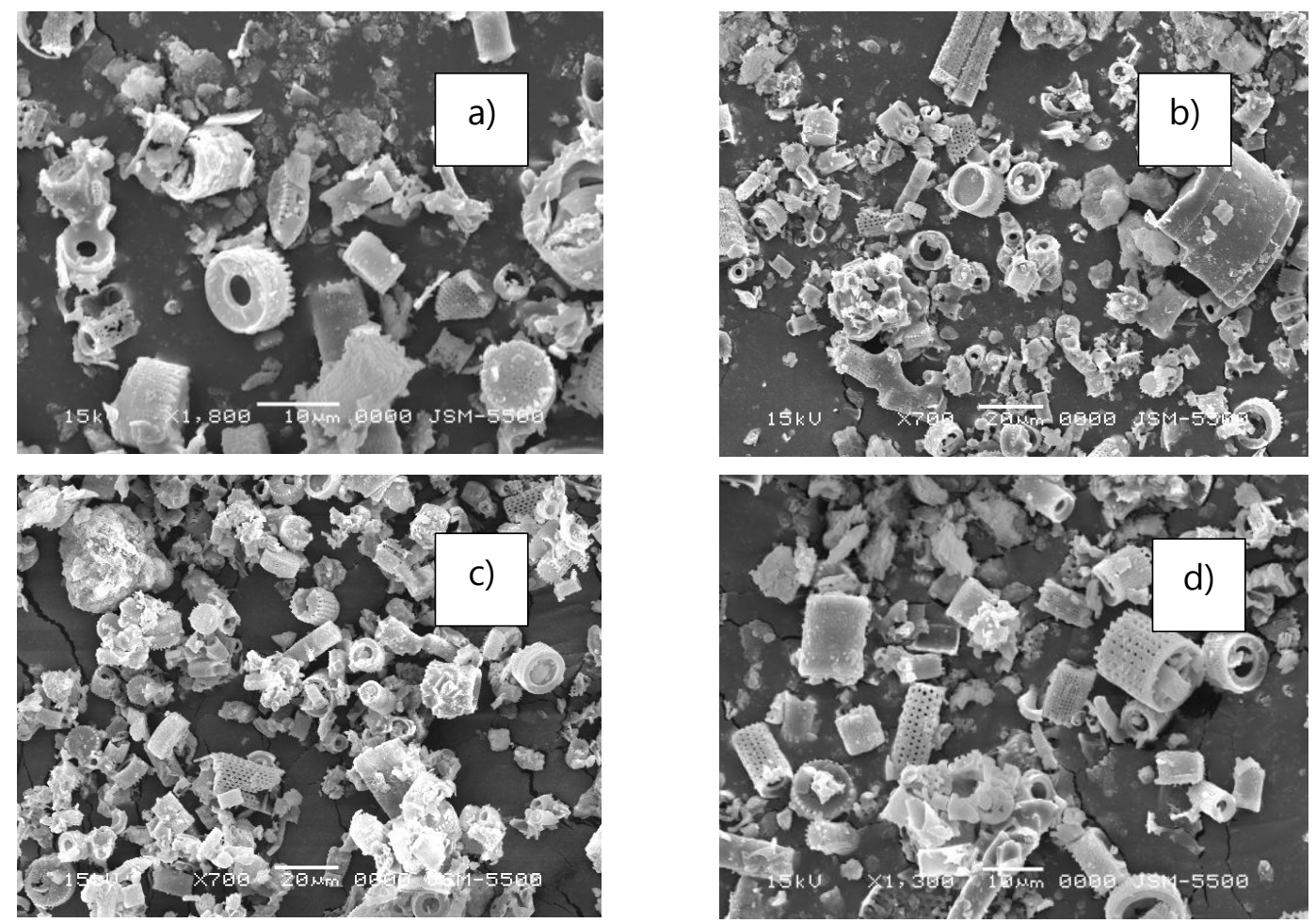

Fig. 1: SEM images of the straight-calcined diatomite and the flux-calcined diatomites with different fluxes: (a) No flux (b) $3 \% \mathrm{w} / \mathrm{w} \mathrm{Na}_{2} \mathrm{CO}_{1}$, (c) $4 \% \mathrm{w} / \mathrm{w} \mathrm{K}_{2} \mathrm{CO} 3$, (d) $5 \% \mathrm{w} / \mathrm{w} \mathrm{NaCl}$

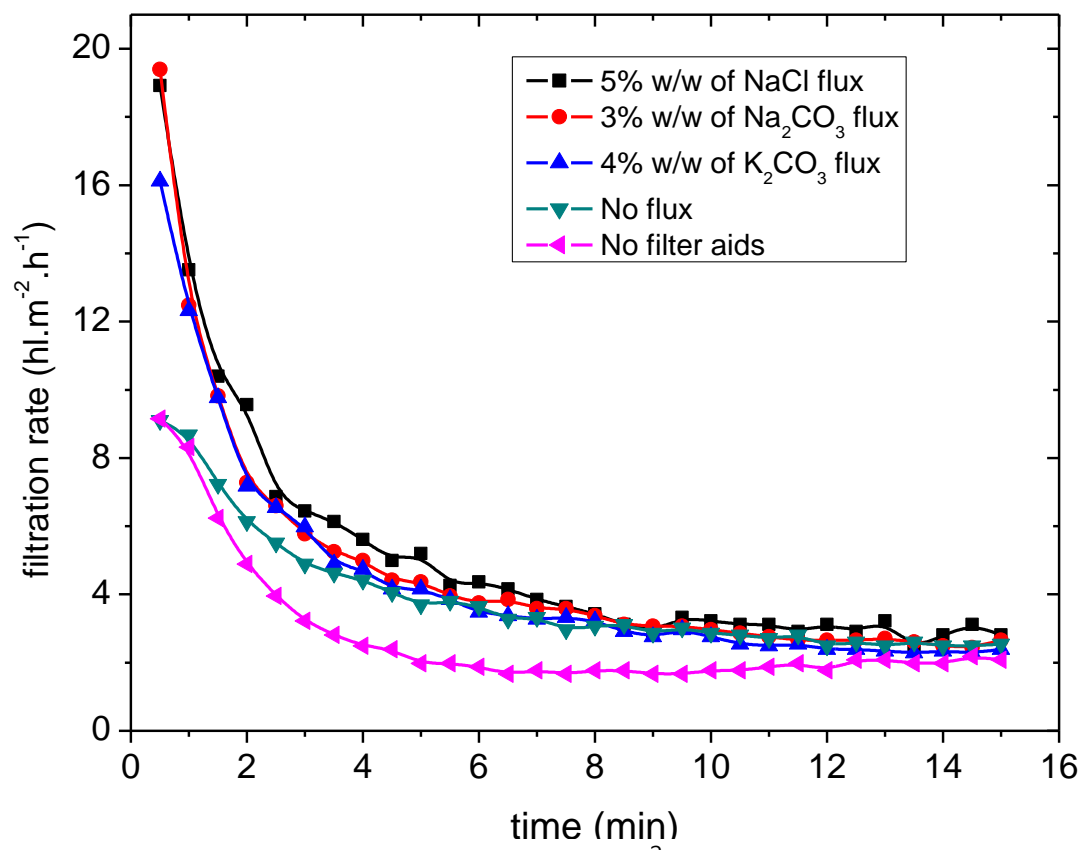

Fig. 2: Instantaneous filtration rate $\left(500 \mathrm{~g} / \mathrm{m}^{2}\right.$ of precoat and $2 \mathrm{~g} / \mathrm{l}$ of bodyfeed)

Beer turbidity increases with increasing of beer color value. From Table 3, it can be observed that, when the beer filtration without filter aids addition, the color of the clarified beer is most turbid (10.3 EBC). To improve beer turbidity, the diatomite filter 
aids were used in the beer filtration process.

The results also show that fluxing agents can considerably affect the clarified beer color. This difference may be due to in calcination, the fluxing agents united with several material oxides and coursed out of the skeletal pores. The pore diameters tend to maximum limits, which make condition for small solids to pass. In addition, the fluxing agents could react with some materials and create minute solid particulates, which go down with clarified beer.

Among the diatomite filter aids used, the filter aid with $5 \% \mathrm{w} / \mathrm{w}$ of $\mathrm{NaCl}$ provided highest average filtration rate. This is in good agreement with its surface structure shown in Figure 1 (d).

In addition, the clarified beer did not change interim of taste and flavor.

\section{Effects of bodyfeed and precoat on filtration}

As reported above, using the diatomite filter aid with $5 \% \mathrm{w} / \mathrm{w}$ of $\mathrm{NaCl}$ can provide highest average filtration rate. Therefore, effects of filter aid content of the precoat and the bodyfeed for beer filtration were investigated based on the diatomite filter aid with $5 \% \mathrm{w} / \mathrm{w}$ of $\mathrm{NaCl}$. The precoat was accomplished by preparing a slurry which contains different amounts of the diatomite powder for each square meter of septum surface area to be coated. The bodyfeed was prepared by mixing the diatomite powder with the raw beer in different ratios.

Effects of bodyfeed on filtration rate and clarified beer color are shown in Figure 3. It can be seen in Figure 3(a) that the filtration rate gradually increases with regularly raising the filter aid content of the bodyfeed. It is observed from Figure $3(\mathrm{~b})$ that at the filter aid content of around $3 \mathrm{~g} / \mathrm{l}$ for bodyfeed, color of the clarified beer was the best. It is also shown that with this condition, the average filtration rate was considerably high.

Figure 4 describes effects of precoat on filtration rate and clarified beer color. It is obviously seen from Figure 4(a) and Figure 4(b) that with the precoat of $400 \mathrm{~g} / \mathrm{m}^{2}$, both the filtration rate and the clarified beer color gave the best result. In particular, the average filtration rate was $5.73 \mathrm{hl} \cdot \mathrm{m}^{-2} \cdot \mathrm{h}^{-1}$ and the clarified beer color was 6.75 EBC.

Table 3. Clarified beer properties (15 minutes of the filtration time) $\left(500 \mathrm{~g} / \mathrm{m}^{2}\right.$ precoat and 2 g/l bodyfeed)

\begin{tabular}{lcccc}
\hline \multirow{2}{*}{ Flux } & \multicolumn{4}{c}{ Parameter } \\
\cline { 2 - 5 } & $\mathrm{pH}$ & $\begin{array}{c}\text { Beer color } \\
(\mathrm{EBC})\end{array}$ & $\begin{array}{c}\text { Average filtration rate }\left(\mathrm{hl} . \mathrm{m}^{-2} \cdot \mathrm{h}^{-}\right. \\
1 \text { ) }\end{array}$ & $\begin{array}{c}\text { Beer taste and } \\
\text { flavor }\end{array}$ \\
\hline No fluxing & 5.4 & 4.7 & 3.91 & Normal \\
agents & 5.4 & 8.1 & 4.57 & Normal \\
$5-\mathrm{K}_{2} \mathrm{CO}_{3} 4 \%$ & 5.4 & 7.3 & 4.78 & Normal \\
$5-\mathrm{Na}_{2} \mathrm{CO}_{3} 3 \%$ & 5.4 & 7.2 & 5.10 & Normal \\
$5-\mathrm{NaCl} 5 \%$ & & & & Normal \\
\hline No filter aids & 5.5 & 10.3 & 1.25 & \\
\hline
\end{tabular}



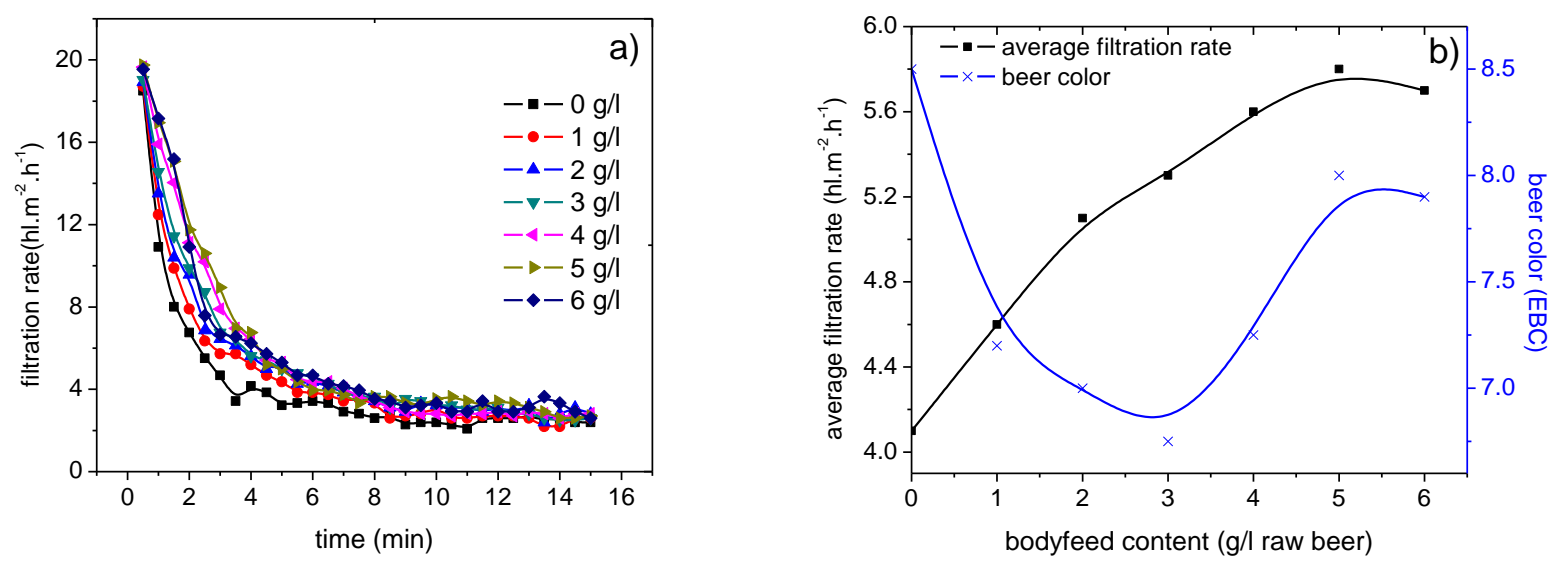

Fig. 3: Effects of bodyfeed on beer filtration $\left(500 \mathrm{~g} / \mathrm{m}^{2}\right.$ precoat $)$
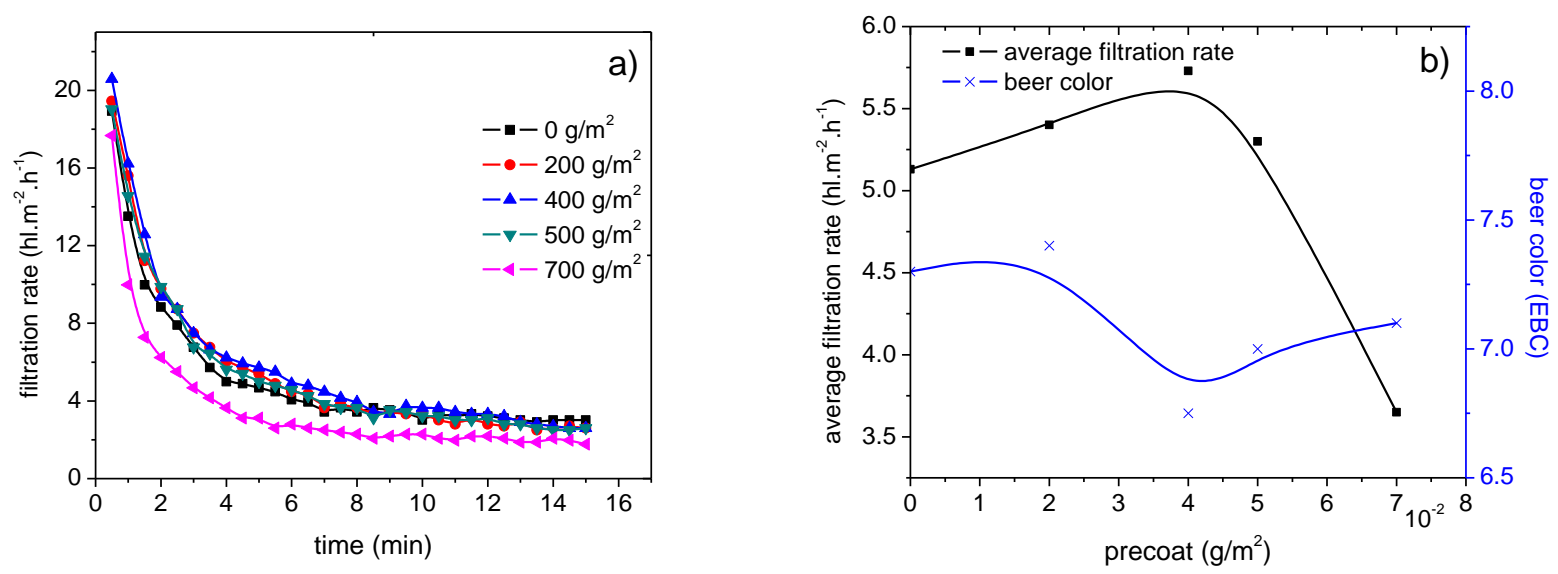

Fig. 4: Effects of precoat on beer filtration ( $3 \mathrm{~g} / \mathrm{l}$ bodyfeed)

Table 4. Heavy metals content in clarified beer $\left(m g . l^{-1}\right)$

\begin{tabular}{ccc}
\hline $\begin{array}{c}\text { Compo } \\
\text { nent }\end{array}$ & Clarified beer & $\begin{array}{c}\text { Standard } \\
\text { (TCVN } \\
7042: 2002)\end{array}$ \\
\hline $\mathrm{As}$ & 0.01 & 0.10 \\
$\mathrm{~Pb}$ &,$- \mathrm{MLOD}=0.06$ & 0.20 \\
$\mathrm{Hg}$ &,$- \mathrm{MLOD}=0.03$ & 0.05 \\
$\mathrm{Cd}$ &,$- \mathrm{MLOD}=0.06$ & 1.00 \\
$\mathrm{Cu}$ & 0.25 & 5.00 \\
$\mathrm{Zn}$ & 0.11 & 2.00 \\
\hline
\end{tabular}

MLOD: method detection limit

Heavy metals content in the clarified beer obtained from the filtration with the precoat of $400 \mathrm{~g} / \mathrm{m}^{2}$ and the bodyfeed of $3 \mathrm{~g} / \mathrm{l}$ was also determined. The results are listed in the Table 4. It is obviously seen that the clarified beer completely meets the standard in terms of heavy metals content.

\section{CONCLUSIONS}

The diatomite collected from Lam-Dong was treated in sulfuric acid, and then calcined with different fluxes to prepare filter aids. The obtained results show that leaching in $6 \mathrm{M} \mathrm{H}_{2} \mathrm{SO}_{4}$ solution for $6 \mathrm{~h}$ and repeated 5 -times, the diatomite became suitable for filter aids preparation. It was also found that $\mathrm{NaCl}$ was the best flux in terms of 
whiteness index and filtration rate among the fluxes studied. Calcined with $5 \% \mathrm{w} / \mathrm{w}$ of $\mathrm{NaCl}$, the diatomite filter aid gave best filtration rates.

In addition, effects of precoat and bodyfeed were also investigated. The results show that using the obtained diatomite filter aid, the appropriate conditions for beer filtration could be the precoat of $400 \mathrm{~g} / \mathrm{m}^{2}$ and the bodyfeed of $3 \mathrm{~g} / \mathrm{l}$. The analysis of heavy metals also shows that the clarified beer completely meets the Vietnamese standard.

\section{ACKNOWLEDGMENT}

The financial support by JICA through SUPREM project is acknowledged.

\section{REFERENCES}

1. Dang, Tran Doan Minh (2011). Preparation of filter aids based on LamDong diatomite. Master thesis, Ho Chi Minh City University of Technology.

2. Fillaudeau, Luc et al. (2006). Water, wastewater and waste management in brewing industries. Journal of cleaner Production, Vol. 14, pp. 463-471.

3. Franca, S.C.A. (2002). Beneficiation of Brazilian diatomite for filtration application industry. SME annual meeting, Feb. 25-27, Phoenix, Ariona.

4. Hossam (2010). Diatomite: Its Characterization, Modifications and Applications. Asia journal of Materials Science. Vol. 2 (3), pp. 121-136.

5. Inglethorpe, S D J (1993). Industrial Minerals Laboratory Manual Diatomite. British Geological Survey. Technical report WG/92/39, Mineralogy and Petrology Series.

6. Martinnovic, Sanja (2006). Preparation of filter aids based on diatomites. Int. J. Miner. Process. Vol. 80, pp. 255-260. Niemsch, K. and Heinrich, Th. (2000). Raible-Test for Evaluation of Filtration Properties. Journal of the Institute of Bre-

wing, Vol.106 (5)

7. Nyamekye, G. A. et al. (2010). Filter aids made from low permeability diatomite. United States Patent 2010/0248953 A1.

8. Peuchot, Christophe (2006). Testing of filter media for liquid filtrationintroduction and review. Institute of Filtration and Techniques of Separation, BP 40292, 4707 Agen, France.

9. Richard B, Nielse (1979). Diatomaceous earth filter aid and method for its manufacture. United States Patent 4,142,968.

10. Richard B, Nielse (1979). Diatomaceous earth filter aid and method for its manufacture. United States Patent 4,142,968.

11. Speers, R.Alex et al. (2003). Effects of bGlucan, Shearing and Environmental factors on the Turbidity of Wort and Beer. Journal of the Institute of Brewing. Publication no. G-2003-0925-137.

12. Stewart, Doug et al. (2000). Development and Assessment of a Small-Scale Wort Filtration Test for the Prediction of Beer Filtration Efficiency. Journal of The Institute of Brewing, Vol. 106 (6).

13. Ward, Ian L (2005). Wort \& Beer Clarification Manual. Brewers Wholesale Supply, Rhode Island 02840. 